\title{
COMMON CRAFTSMANSHIP IN THE AEGEAN AND EAST MEDITERRANEAN BRONZE AGE: \\ PRELIMINARY TECHNOLOGICAL EVIDENCE WITH EMPHASIS ON THE PAINTED PLASTER FROM TELL EL-DAB'A, EGYPT
}

By Ann Brysbaert

\section{Introduction}

Since the spectacular discovery of the painted plaster fragments at the site of Tell el-Dabca in 1989, much attention has been paid to the iconographical study of its scenes, more specifically in relation to the well-known Minoan and Mycenaean painted plaster fragments of Bronze Age Greece (e.g. DAVIES and Schofield 1995, Poursat 1999: 181-194). Early on it was clear that, from an iconographic point of view, the thousands of fragments found in the eastern Nile Delta did not fit the typical Egyptian painting tradition, as we know it from many Middle and New Kingdom sites. M. Bietak, the director of the Austrian excavations at Tell el-Dabca, suggests to date these painted plaster fragments to the first half of the $15^{\text {th }}$ century BC (which may include the early years of the reign of Tuthmosis III) (BIETAK 2002: pers.comm.).

The first part of this paper, the evidence section, will focus on the dimension of technological features observed on the Tell el-Dab ${ }^{\mathrm{c}}$ a plaster material. Consequently, the second part, the discussion, will provide comparative evidence in support of an apparently common technological background and knowledge between parts of the Aegean and the Eastern Mediterranean Bronze Age cultures concerning the execution techniques and applied materials involved in painting plastered surfaces. Since this paper frames within my ongoing doctoral research no conclusions are made yet as to the direction of technological transfer within this

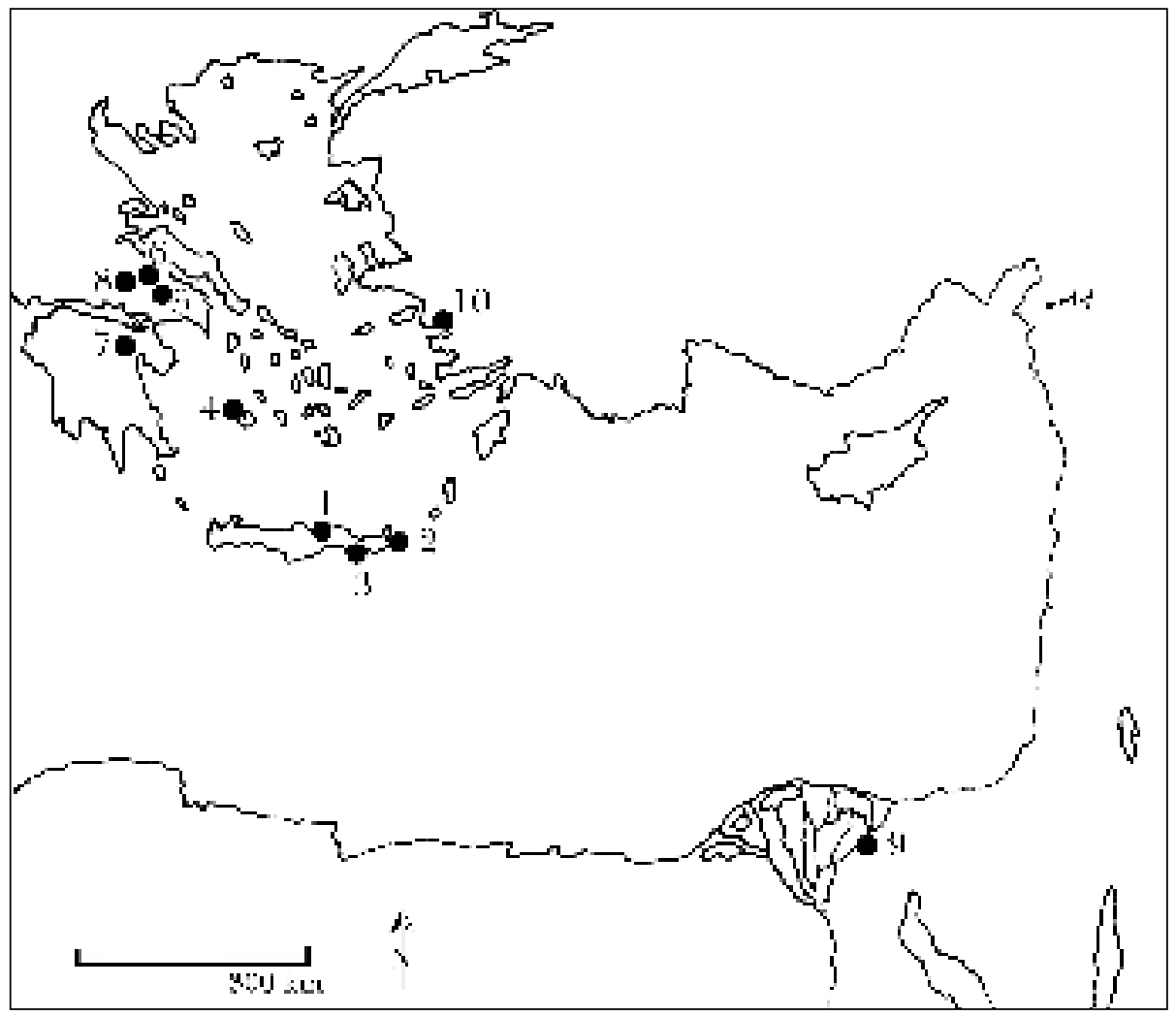

Fig. 1 Map of the Aegean and East Mediterranean indicating the discussed sites $1=$ Knossos $/ 2$ = Palaikastro $/ 3=$ Myrtos-Pyrgos $/ 4=$ Pylakopi $/ 5=$ Thebes $/ 6=$ Glas $/$ $7=$ Mycenae $/ 8=$ Orchomenos $/ 9=$ Tell el-Dab ${ }^{c} a / 10=$ Miletus $/ 11=$ Tell Alalakh 
region at the height of its development. This will be possible after the analytical work has been carried out.

The presented results from Tell el-Dabca and all other mentioned sites, listed above, are based on personal macroscopic and microscopic observations (Scanning Electron Microscope excluded) unless stated otherwise, and ongoing experiments including replication work. Analytical data from the existing literature is included where relevant.

\section{The evidence}

In this section of the paper, the technological features observed at the plaster from Tell el-Dabca are outlined and examples form the illustrations to clarify each feature. A numerical system from 1 to 14 is given to each different feature of the evidence. This evidence can best be divided into two main points:

- Surface treatment

\section{- Materials composition}

The term 'surface treatment' is used here as a general term to describe both technical features related to the act of painting onto the surface as well as any activity related to creating the decorated surface, whether previous to or after the painting execution. 'Materials composition' refers both to the plaster body or substrate and to the used pigment mixtures. The sites included for comparative purposes in this paper are the following and have all been studied as primary material by the author (Fig. 1):

- Aegean: Knossos, Palaikastro, Myrtos-Pyrgos (Crete), Pylakopi (Milos), Thebes, Glas, Mycenae and Orchomenos (Greek mainland),

- Eastern Mediterranean: Tell el-Dabca (Egypt), Miletus, Tell Alalakh (Turkey).

The study of the painted plaster material from the sites of Monastiraki (Crete), Tiryns (Greek mainland) and Tel Kabri (Israel) is in process or planned. Therefore, results are not included in this paper.

\section{Surface treatment}

Without going into the ongoing debate about whether the fresco or the secco or a combination of techniques were used in the execution of Bronze Age Aegean painted plaster, it is clear to all who study its technology that at least part of the evidence points towards the use of the al fresco technique. Most recently, it was restated that

'The majority of the pigments of the Theran wall paintings were applied in fresco technique, but the secco technique was also used' ( PERDIKATSIS et al. 2000: 116).

This statement reflects the general observation of many scholars studying Bronze Age painted plaster in the Aegean. Possibly due to the fragmentary nature of the material no study has ever dealt with the in-depth study of which part/percentage exactly was painted al fresco and what was executed al secco and whether there were patterns or any form of standardisation to discern in these observations across the Aegean (and indeed the Eastern Mediterranean), or whether we look at a very regionally based set of features. This paper does not claim to provide irrevocable answers to this question but wants to raise this point and wants to show that there is more evidence related to fresco painting of details as was previously pointed out.

Based on the macroscopic and microscopic study of the painted plaster from Tell el-Dabca, the following observations have been made:

1) Single and concentrated groups of fingernail impressions (and occasional finger and knuckle prints) have been found, especially on painted plaster with small-scale scenes, on painted plaster from Tell el-Dabca. Examples are around the body and face of the 'priest' (cat.nbr. F 46-8427), an acrobat (cat.nbr. F 7-8425) and white animal scenes (F 294), in general: from area $\mathrm{H} / \mathrm{I}, \mathrm{H} / \mathrm{III}$ and $\mathrm{H} / \mathrm{IV}$. (Pl. 1, Fig. 2).

2) Specific small details such as (edges of) clothing and facial features (eyes, beard, hair and eyebrows) are built up first in a thin clear-cut plaster outline, then painted over in black or in another colour where required. This is in contrast to what was stated before (SEEBER 2000: 102: discussion section). Tell el-Dabca has some very clear examples to illustrate this: the priest figure, the bearded man from H/I (cat.nbr. F 6-8424, F 46-8427), the outline of the bodies of the large scale figures (cat.nbr. F 577). From area H/IV, we have cat.nbrs. A 26 and A 85 a showing this phenomenon too. The design here is a spiral motif. This way, not only do we see a relief effect but the applied extra white thin layer also covers the incised lines that were left in the plaster to form a guide for the subsequent painting.

3) Building onto the previous point, larger areas that had to be painted over a coloured surface/background received a similar preparation of a white 'base' in plaster over the coloured background, which were then covered with paint. Extra fine details onto these areas or adjoining to it were usually added without extra preparation. This is especially clear for the white lilies (cat.nbrs. F 22, F 501) where 
the 'body' of the flower forms a slight relief in white plaster. In contrast, the stems of the flowers are just painted thinly onto the red background. The same can be seen for other floral elements at Tell el-Dabca such as the blue leaves on red background from H/I (cat.nbr. F 4-7997) (Pl. 2). This contrasts against what was observed earlier (SEEBER 2000: 102: discussion section). Similarly, this technique was noted on animal scenes over red backgrounds (Ungulates) or on yellow backgrounds (lions) from building $\mathrm{H} / \mathrm{I}$. The fingernail imprints are again a proof of the execution of this painting in al fresco.

4) Egyptian blue pigment is often applied onto a rougher surface than it is the case for other pigments at Tell el-Dabca. In many instances it looks as if the specific area that is supposed to receive the
Egyptian blue, has either been roughened on purpose (maybe by pressing or gently pecking it at the kind of micro-level of maximum $1 \mathrm{~mm}$ deep) or was left rougher during the flattening stage of the plaster before the pigment was applied. This is clear on the blue leaves painted on the fragment depicting the leopard (cat.nbr. F 9-8426), the bull leaper (cat.nbr. F 4-7997) and several others: cat.nbrs. F 11, F 417, F 176, F 178 and, very clearly on F 435 (floral motif).

5) The use of a non-rigid form of templates has been observed at Tell el-Dabca and was reported upon (BIETAK et al 2000: 88-89). More rigid forms are now recorded related to more simple and abstract iconographic elements. Via the use of raking light I noticed that a string of the same leaves

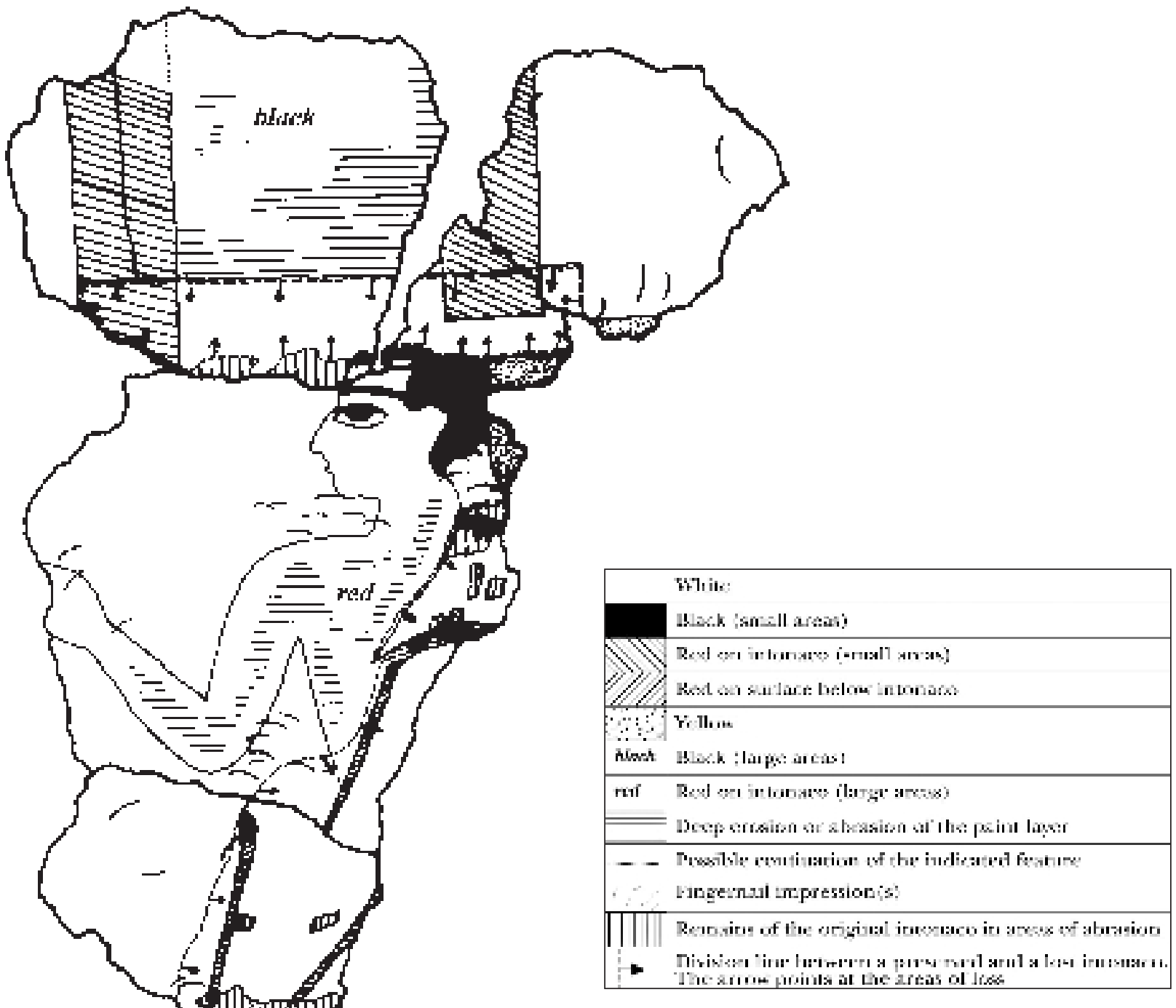

Fig. 2 Condition map, including technological features, on the painted plaster fragment of the 'priest', Tell el-Dab'a (drawing: Ann Brysbaert, scale 1:1) 


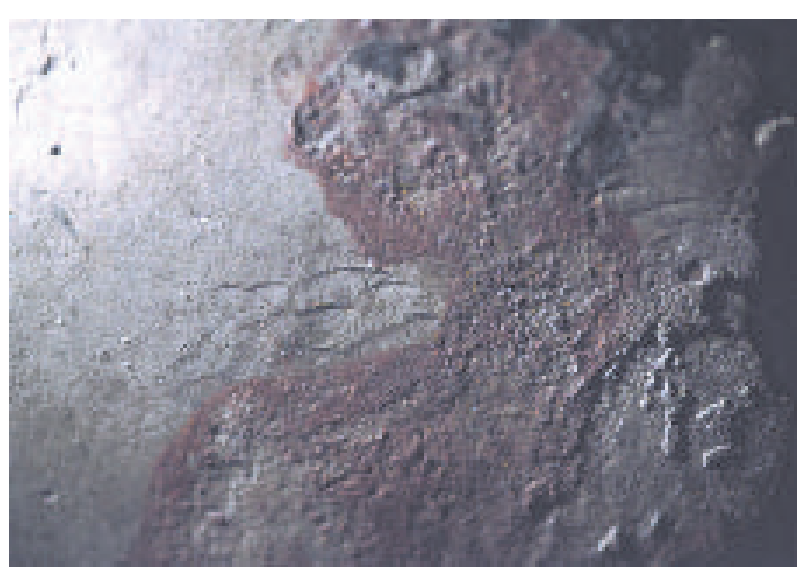

Pl. 1 Fingernail impressions around head and body of the 'priest', Tell el-Dabca

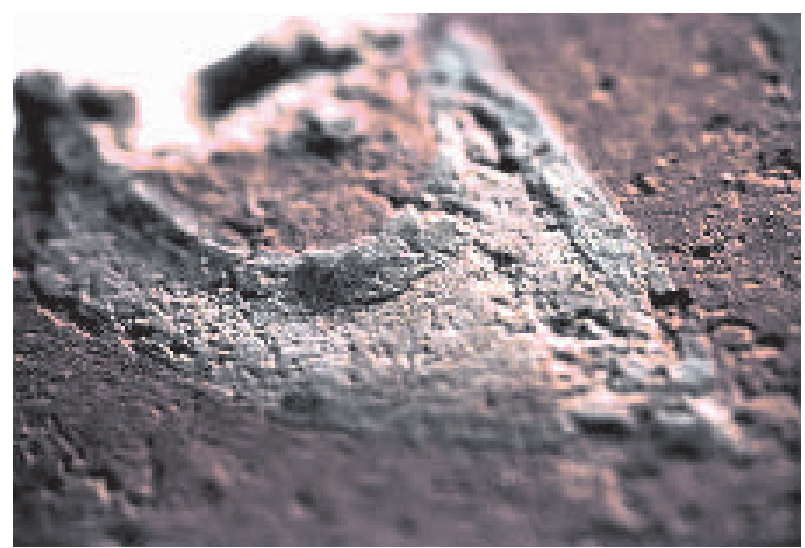

Pl. 2 Raised outline in plaster and painted over, bearded man's eye, Tell el-Dabca

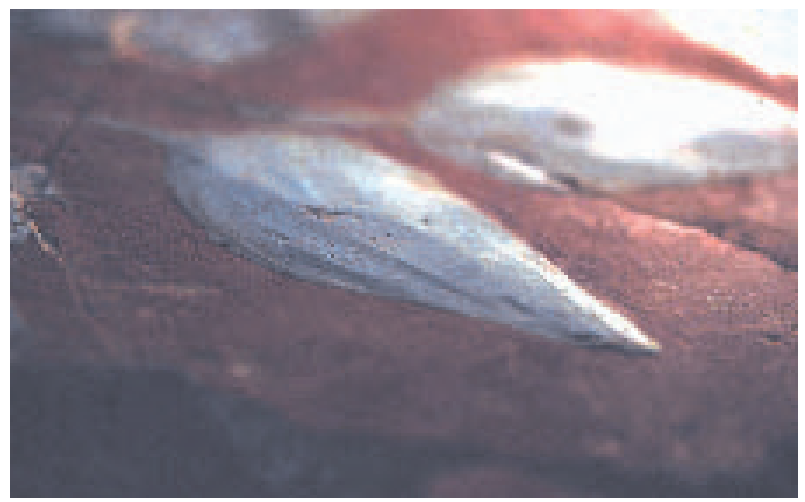

Pl. 3 Locally raised plaster details of leaves, painted over in light blue over red background, Tell el-Dabca

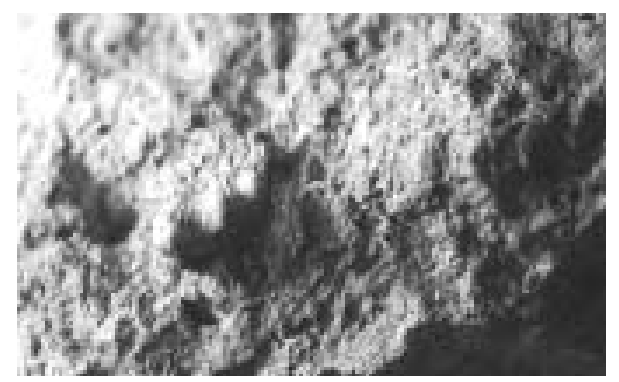

Pl. 4 Crushed Murex shells within plaster matrix,Tell el-Dabca

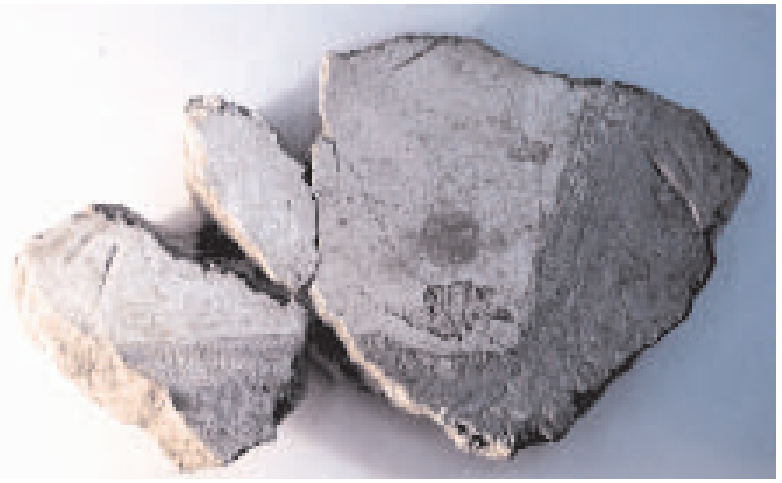

Pl. 5 Locally indented area in painted plaster surface to recieve Egyptian blue (Thebes Museum, Glas)

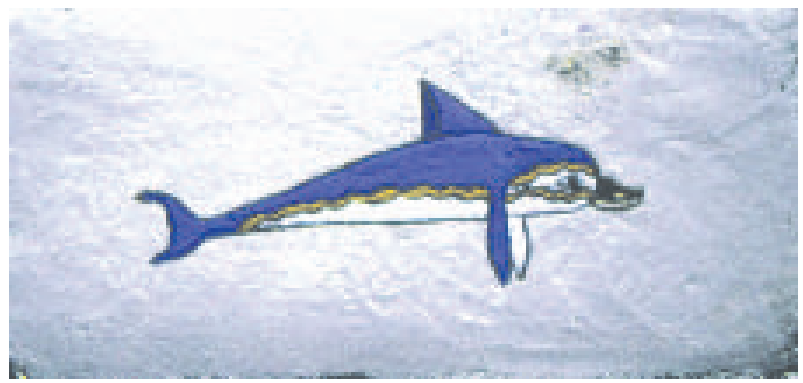

Pl. 6 Experimental work showing the effect of trowelling onto the surface, done before painting when plaster was still wet and malleable

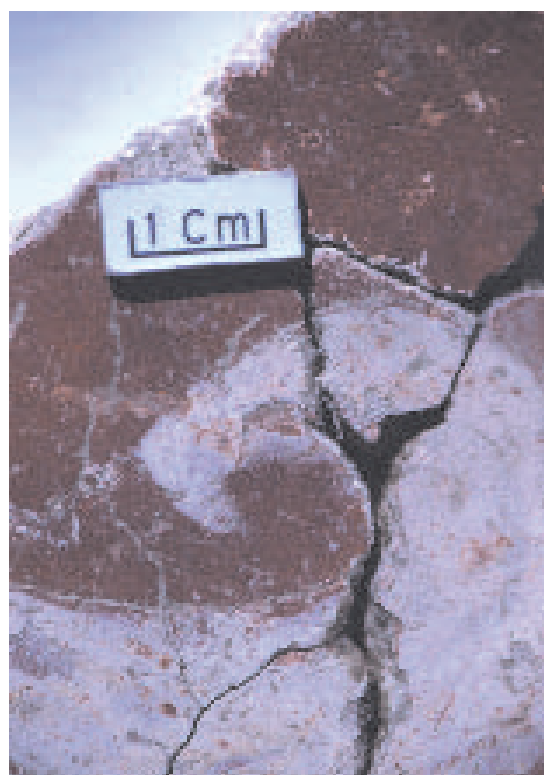

Pl. 7 Incised lines as preparation to paint the white lily motif onto a red background, Miletus

All photographs by Ann Brysbaert 
were all slightly indented into the surface and apparently paint was applied over this indentation as seen on the acrobat fragments (cat.nbr. F 7-8425) or on the string of ivy leaves (cat.nbr. F285).

6a) The green painted surfaces seem to have been built up by applying yellow paint over Egyptian blue pigment at Tell el-Dabca. Examples are cat.nbr. F204 showing green palm leaves and F 411: green leaves on red branches. Also on large size fragments, such as the griffin fragment the green is painted in the way just described (cat.nbr. F 32).

6b) A dark blue is obtained by painting black over blue, in the case of Tell el-Dabca: Egyptian blue. No catalogued examples can be given but this phenomenon was clear especially from the area $\mathrm{H} / \mathrm{I}$ and $\mathrm{H} / \mathrm{IV}$. In contrast to this but less often so, one also finds fragments where blue is painted over black from the same areas.

7) At several instances (for example cat.nbrs. $7995,8427)$ clear tool marks, left in the still soft plaster surface from trowelling or polishing it (probably with a stone or pebble), are visible at the Tell el$\mathrm{Dab}^{\mathrm{c}}$ a fragments (see also from area H/IV: cat.nbrs. A73, A 87). These marks only make real sense when the true fresco painting technique was intended to be applied. The trowelling and polishing of the surface just before painting has the function not only of flattening the surface but also to press the surface so that the lime gets drawn to the surface. This in itself will then form a lime-richer, thus whiter surface. It will be a harder surface upon drying due to the applied pressure and, most importantly, it will 'lock in' the applied pigments much better upon drying of the surface (cat.nbr. F 465 and several fragments of area $\mathrm{H} / \mathrm{III})$.

8) At several occasions, the outline of specific elements or motifs was outlined into the plaster by an incised line in the receiving background before the paint was applied onto the background. This was most clear at the execution of the 'body' of the white lilies (cat.nbrs. F 22, F 501) onto the red background. Other examples at Tell el-Dabca are outlines scratched into the plaster (painted in at a later stage and not done following the lines perfectly) on the griffin scene (cat.nbr. F 158).

9) In many instances there was clear evidence of colouration of the surface below the painted surface at Tell el-Dabca. This became evident where the top surface (painted intonaco) had flaked off or was eroded away enough to reveal the layer underneath. This colouration was most often carried out in yellow or red. Examples are visible on several fragments of the plaster from the areas of $\mathrm{H} / \mathrm{I}, \mathrm{H} / \mathrm{II}$,
$\mathrm{H} / \mathrm{III}$ and $\mathrm{H} / \mathrm{IV}$, and possibly more clearly on cat.nbrs. A 37-F47, F8 and F46-8427 (Pl. 3).

\section{Materials composition}

In the context of this study, the plaster as a substrate or carrier for pigments and the pigments themselves are considered. No references to backing support for the plaster (e.g. mudbrick surfaces, stone faces, wooden beams and organic woven support systems) are made.

From the material from Tell el-Dabca, the following observations were made:

10) The Egyptian blue pigment used at Tell el$\mathrm{Dab}^{\mathrm{c}} \mathrm{a}$, contained a copper alloy rather than pure copper as a blue staining element. This alloy was stated as being copper with tin (SEEBER 2000: 102: discussion section).

11) In the plaster mixture of the thick plaster fragments at Tell el-Dabca, especially the fragments found in areas $\mathrm{H} / \mathrm{I}, \mathrm{H} / \mathrm{III}$ and $\mathrm{H} / \mathrm{IV}$, I detected a certain amount of crushed shells mixed in very well within the plaster matrix (Pl. 4). Upon closer inspection I could identify these shell fragments positively as Murex species, both trunculus and brandaris (see for instance TORNARITIS 1987: 80-4). Moreover, during the short excavation season at Tell el-Dabca (area H/I) in the Spring of 2001, three small deposits of crushed Murex shells were recovered preliminarily dated to an $18^{\text {th }}$ dynasty context.

12) A small simple chemical test proved that the plaster used in the different areas at Tell el-Dabca was almost purely lime plaster. This observation needs further analytical research and confirmation.

13) The reuse of older plaster fragments in the matrix of later plaster has been observed at Tell el$\mathrm{Dab}^{\mathrm{C}} \mathrm{a}$ at a few occasions (cat.nbr. F 436) and in the thickness of the griffin plaster material (cat.nbr. F158). In the mentioned fragment the recycled fragments were not painted.

14) At Tell el-Dabca several fragments clearly show a layered stratigraphy of paint and plaster layers on top of each other (for example cat.nbr. F 746 and several examples from area $\mathrm{H} / \mathrm{IV}$ ). It is of course not possible to state how much time there was in between the two phases of painting before a new, rather good layer of plaster was applied onto the painted surface and painted again. This should not be confused with the the possible use of sinopie.

\section{Discussion}

In the discussion reference is made to the evidence section by using the same numerical sequence (1-14). When specific features needed further 
explanation, this is done here. Comparanda from the above mentioned sites is outlined in its relation to the Tell el-Dabca material.

\section{Surface treatment}

From the evidence outlined in points $1-3$ and 5 , it is clear that we have proof for al fresco painting. As we will see, this is very comparable from what we know from the Aegean paintings in contrast to what is known from the rest of the Egyptian material from this period (discussed in length elsewhere: LEE and QUiRke 2000: 104-120, El GORESY 2000: 49-70, DAVIES 2001).

1) The presence of clear signs of the application of the al fresco technique is visible for instance as fingernail impressions, certain tool and brush marks, the use (or absence) of specific pigments, and the use of lime plaster. This was already noticed on plaster fragments from Knossos (CAMERON, Jones and PhilipPakis 1977: 169) and I found more such evidence during the study of the Knossian fragments housed at the Ashmolean museum at Oxford. The same features showed up during my study of the material from Palaikastro, Myrtos-Pyrgos, Thebes, Mycenae, Glas, Orchomenos, Phylakopi, Miletus and Tell Alalakh.

2) Very similar evidence comes from the Knossian material from the Ashmolean Museum and the fragments from the 1997 excavations at Thebes (the small procession scene), and Glas (dolphin painting), and was in fact common all over the Aegean according to M. Shaw (SEEBER 2000: 102). This not only provides a very clean linear and detailed effect but also indicates a very light form of relief when viewed with raking light. This technique of painting, seen at the eye of the priest at Tell el-Dabca compares very well with the execution of the loin cloth at Knossos (Ashmolean Museum, cat.nr. A.E. 1862). Moreover, there is clear proof of the fact that such prepared detail is executed al fresco marked by fingernail concentrations around such areas. In my view there is no other reason why such a concentration should be there otherwise.

3) The same effect of raised surfaces in plaster is noticed at Miletus, Phylakopi and Amnissos (SCHAEFFER 1992: 220) for the white lilies on red background. Other examples of this technique were also observed on the painted plaster from Glas, Thebes, Myrtos-Pyrgos and Knossos. This feature often marked spiral or floral motifs.

4) I made similar observations at Palaikastro (Brysbaert 2000: 53), Knossos, Thebes, Miletus, and Phylakopi. In some cases it looks as if the intonaco was not applied onto the rougher layer beneath where the Egyptian blue was next applied. This is clear in an example from Glas (Pl. 5). An extreme example of this is the Egyptian blue pigment applied on the rough surface of the natural kouskouras at the ceiling of the Temple Tomb at Knossos (BRYSBAERT: in preparation). The Egyptian blue pigment, frequently used in Egypt, the Near East and the Aegean during the Bronze age, is in fact a synthetically made material, often wrongly called glass or frit, that is crushed in order to become usable as a pigment. In contrast to most other inorganic pigments such as the yellow and red ochres, Egyptian blue exerts a stronger hue when its grain size is larger. This effect is even more enhanced when the Egyptian blue is applied in a thicker coat or multiple coats, without any addition of lime to tone its hue down. Other aspects affecting its colour intensity are discussed in the literature (Tite 1986: 39-41, TiTe and Bimson 1987: 81-5). If one would crush up Egyptian blue to obtain the same grain size as the ochres when used to paint, it would be more or less completely transparent or colourless. This bears a serious consequence as to its application possibilities onto a plaster substrate and its penetration capacity in the plaster mass. This pigment is frequently applied in the fresco technique which means that it is applied without any additional binder added to the pigment, suspended in water, before it is applied onto the damp wall.

5) The feature of templates has been thought of before. At Akrotiri, another method of, apparently, facilitating the paintwork has been described recently as the use of a modular line system (BIRTACHA and ZaCHARIOUdAKIS 2000: 159-172). The use of templates at Akrotiri, possibly at Amnissos and at Tell el$\mathrm{Dab}^{\mathrm{C}} \mathrm{a}$ was applied when the plaster was still wet as we can clearly see the imprint of the template into the plaster surface. The painting of the iconographic element may have been executed both al secco or al fresco or combined. Only fingernail concentrations around these elements can prove pure fresco.

6a) Obtaining a green surface by applying blue with yellow has also been noticed at Palaikastro, Knossos, and Thebes. However, quite some time ago, one green pigment sample has been identified as malachite from Tiryns (for a good review on past analytical work see JONES: in press). This has been the only case up to date where malachite has been found in the Aegean. I, therefore, would like to reinvestigate this material to verify its identification and to rule out the possibility of the material being a 
weathering product of Egyptian blue. In this context, Goresy discards two green pigments as 'pigments': secondary basic copper chloride (paratacamite) and secondary malachite because both are weathering products of the glass phase of Egyptian blue (EL GORESY 2000: 61-2 LeE and QUIRKE 2000: 112).

In this context mention should be made of a specific green pigment, 'green frit' or wollastonite, that became in frequent use in Egyptian tomb paintings only since the start of the $18^{\text {th }}$ dynasty, immediately after the Hyksos period. This pigment has been identified in the tombs of the soldier Ahmose, Paheri and Renni at El Kab, and in Salem's tomb at Edfu. As with some of the Egyptian blue, this pigment also contains tin-copper as a colouring element and has, as such, been considered as a new technological achievement in the $18^{\text {th }}$ dynasty in Egypt (EL GORESY 2000: 69).

As far as I am aware of the use of green pigment in the Aegean Bronze Age period, no such identification of green has been made yet. Although I do not wish to base my conclusions solely on microscopic observations, I did not see any positive use of 'green frit' as a pigment in Tell el-Dabca either. Instead, green always seemed to be a mixture of Egyptian blue with a yellow pigment, most probably yellow ochre, as we commonly find it in the Aegean. Under a simple microscope it was not clear, however, whether this green pigment was obtained by mixing blue and yellow (in a bowl or on the palette) before painting or whether each layer was applied separately. In most cases, both blue and yellow grains could be clearly seen separately under the microscope using magnifications in the range of $\times 20-\times 60$. A few times I could see yellow over blue but since the yellow layer was applied rather thickly, it is not clear whether the blue would have been visible through the yellow to visually form green. The apparent absence of wollastonite or 'green frit' at Tell el-Dabca can be interpreted preliminary in two different ways:

- The paintings in Tell el-Dabca were not painted by painters who knew this new green pigment and, therefore, they may have been foreigners, possibly from the Aegean,

- The paintings at Tell el-Dabca were executed before the $18^{\text {th }}$ dynasty. However, since the paintings at Tell el-Dabca are considered to have been executed some time after the reign of Ahmose, possibly even as late as the early phase of the reign of Tuthmosis III (BIETAK 2002: pers. comm.) this is now unlikely according to the excavators. 6b) No black on blue as a painting technique has been noticed yet macroscopically in the Aegean from the other sites in the Aegean that I have worked on, apart from the material from Miletus where the same procedure was followed in several cases. The blue in Miletus, however, was never of the same intense colour as at Tell el-Dabca so the overall colour effect is more grayish. This may be due to a variety of reasons: the use of a different blue pigment, or the application of Egyptian blue with a smaller grain size, or the mixing of a different black substance with the blue, or a different relative quantity of the two colours. In the case of this colour combination we can clearly distinct two separate layers rather than a mixture of pigments, as it may be the case to obtain the green hue by using blue and yellow pigments.

7) Tool marks from trowelling have been seen at all fragments of earlier mentioned sites that show signs of true fresco painting. Moreover, the real implication of this trowelling on pigment locking in the course of fresco painting became clearly understood during my experimental work where a much whiter and harder surface was obtained when trowelling was carried out well. This trowelling (and possibly polishing?) of the surface happened at least once before any painting or surface preparation was carried out (Pl. 6). One can actually see the lime coming out of the matrix and settling above the filler that is pressed into the mass during the action of trowelling. Exactly this phenomenon may explain one of the reasons why the experimental work on polishing after painting, carried out by the Akrotiri team did not seem to work (Chryssikopoulou et al. 2000: 123-125). However, Cameron did seem to be successful with his experiment (CAMERon et al. 1977: 165).

8) The phenomenon of incised lines to delineate where the paint has to be applied onto the background is a common feature in Aegean painting and can aid in applying the intended paint faster and more correct. Identical proofs of this were observed at Miletus (Pl. 7) and Phylakopi where white lilies were executed as described for Tell el$\mathrm{Dab}^{\mathrm{c}} \mathrm{a}$. The lily frescoes from Amnissos were also executed in the same way (SCHAEFFER 1992: 220). The described feature may also be related to the use of templates whereby the artist would incise in the wet plaster, following the contours of the form of the cut-out template. This technological feature, together with the string impression (also abundantly present at Tell el-Dabca and all other mentioned sites), are no water tight criteria for fresco painting since all of this could have been done prior to the complete 
drying of the plaster. The pigments could then have been applied in al secco afterwards.

9) Although it cannot be stated with a $100 \%$ certainty that these colourations were the preliminary sketches (or sinopie), since there was not enough visible, as they were known in the Rennaissance period by the buon fresco painters, we can assume that at least some, if not most, of these lines had such a function. The problem is that, most often we do not have enough evidence of such areas to state that the little corners we see revealed show lines of sinopie only. We can say, however, that such evidence has been reported for Knossos (CAMERon et al. 1977: 167) and has been referred to by the experiments for Akrotiri (Chryssikopoulou et al. 2000: 123). Interesting, however, was the comment made by Renfrew (SEEBER 2000: 102) that, once the intonaco was applied on top of this sinopia, one would not be able to see this sinopia anymore. This remark verbalized my concern about the idea of sinopia on Bronze Age paintings and makes perfect sense since even a lime wash would already obscure the entire layer underneath upon drying. From this we need to conclude that this sinopia must have fulfilled another function than a visible guide to the painters while they were executing the final iconographic theme. In that case, one can understand it as a 'dry run', just to see if the planned design fitted onto the wall (see also M. SHAW's comment in SEEBER 2000: 102: discussion section).

\section{Materials composition}

10) The copper alloy, rather than pure copper as a colouring agent has been found in the Egyptian blue pigment from a few contemporary sites in the Aegean such as Knossos, Mycenae and Akrotiri (FILIPPAKIS et al. 1976: 143-53, FILIPPAKIS 1978: 599-604). The presence of tin-rich minerals in the Egyptian blue pigment has been detected since the reign of Tuthmosis III onwards (1479-1425 BC) while arsenic bearing phases were dominant in the used copper alloys from the moment copper alloy filings were used in the $5^{\text {th }}$ Dynasty (OGDEN 2000: 152-153) until at least the end of the reign of Hatshepsut (1479 BC) (EL GoresY 2000: 60, Lee and Quirke 2000: 109). This interesting phenomenon could possibly reflect the composition of the copper alloys used at those times in Egypt (EL GORESY 2000: 61, 65). Ogden stated that tin was purposely present in copper to obtain bronze quite early onwards but still only in a minority of objects by the Middle Kingdom period (OGDEN 2000: 153-4).

The Egyptian blue used at Tell el-Dabca plays an important role in this distinct chronological distri- bution of arsenic and tin in copper alloy used for Egyptian blue pigments. The paintings, according to M. Bietak, all belong to the same time range that corresponds to the earlier phase of the palace (Str. $\mathrm{d}=$ Phase $\mathrm{C} / 3$ ). The later phase of the palace corresponds with Str. $\mathrm{c}=$ Phase $\mathrm{C} / 2$ and dates from the time of Tuthmosis III until Amenophis II or even Tuthmosis IV.

The phenomenon at Tell el-Dabca can be carefully looked at in two different ways since chronology plays an important role here:

- The Egyptian blue at Tell el-Dabca comes from somewhere else where the copper-tin alloy was in use earlier than in Egypt or

- This may be the first, and currently the only, evidence for the fact that the tin-copper alloy based Egyptian blue was in use in Egypt since at least the early $18^{\text {th }}$ dynasty and before Tuthmosis III if the paintings were executed during the first quarter of the $15^{\text {th }}$ century BC and before the reign of Tuthmosis III.

What we do know, as far as the Aegean is concerned, is that tin-copper alloys were used to produce the Egyptian blue used at Akrotiri at a time earlier than the early $18^{\text {th }}$ dynasty (LeE and QUiRKe 2000: 110-1). So this evidence could be a scientific proof for the fact that there was at least a transfer of pigments, especially Egyptian blue, from the Aegean to Egypt. However, this sounds very odd since Egyptian blue was very well known in Egypt and, therefore, did not need to be imported. One could go a step further and state that this tin-copper bearing Egyptian blue travelled with its user who may not have known what was locally available or who had personal preferences to use his/her own materials. This does not explain, however, why the Egyptian blue hue on the plaster fragments at Tell el-Dabca is so much more intense than the coats found on many of the Aegean painted plaster, apart from Knossos. Possible explanations for this are:

- The Egyptian blue in the Aegean is more often mixed with lime to tone down its hue intensity

- The use of another blue pigment, an amphibole in quite a few cases, used purely or in combination with Egyptian blue, may be more common in the Aegean paintings than previously thought (see Cameron et al. 1977: 141; Perdikatsis et al. 2000: 113-114; DANDRAU 1999: 117-118; JONES: in press)

- The coats are painted thicker (or multiple) at Tell el-Dabca 
- The grain size of the pigment is larger at Tell elDabca

- The surfaces of the excavated plaster fragments are better preserved at Tell el-Dabca

- The plaster surfaces are better prepared and, therefore, hold better the Egyptian blue pigment at Tell el-Dabca.

Several of these suggestions refer to a different technological factor than what was in use in the Aegean although we are far from complete in our knowledge about the use and manipulation of pigments as raw materials within the Aegean painted plaster craft. This aspect certainly deserves more attention and analytical combined with experimental work to clarify these points is in progress.

11) The use of Murex shells for dying purposes is well attested in the Near East but its presence within plaster has, to my knowledge not been reported upon before my observation was made at Miletus. Also the Tell el-Dabca material seems to be the earliest known and first reported lime plaster material containing such crushed shells in the geographical area of Egypt. No mention at all of the presence of these shells for any use was made the latest publication on Egyptian material and technologies (NichOlsON and SHAw 2000) although the three Murex species were observed in the area of the north-eastern Delta area during the second millennium and mollusks were present at Tell el-Dab ${ }^{\mathrm{c} a}$ in the period from the early $12^{\text {th }}$ dynasty onwards (1970-1920 BC) until the end of the $2^{\text {nd }}$ Intermediate Period (ca. 1540 BC) (Murex was not specifically mentioned in relation to Tell el-Dabca, based on the finds excavated between 1966-'69 and 1975-' 86 but can be assumed to be there, see BOESSNECK and VON DEN DRIESCH 1992: 44). Tell el$\mathrm{Dab}^{\mathrm{c}} \mathrm{a}$ was connected to the sea by its location along the east side of the Pelusiac branch of the Nile (DORNER 1999: 77). It was known from inscriptions that Avaris had a port with the necessary installations for ships to disembark, coming from the Mediterranean (BieTaK 1994: 37). From the literature it is clear that seafaring contact between Tell el-Dabca and the Mediterranean Sea was very flourishing. However, nowhere it is clear how easy and fast one could make the trip from the site to the coast. The presence of the shells, in any case, show a clear case of Mediterranean influence and their presence at Tell el-Dabca, therefore, it nothing extraordinary. But what are these shells doing there and how did they get there? Two options come to the foreground: 1) textile dying using the famous royal purple dye, extracted from the Murex gland or 2) seafood consumption.

1) Within the context of what has been found at Tell el-Dabca it is quite clear that these Murex shells were not the remains of a textile dying workshop. First of all, no more than half a kilo of crushed shells has been found within the context of relevance to this discussion. This is not nearly enough for dying purposes. Moreover, Ruscillo and Reese stated that the Murex species have to be alive at the time of being processed for the dying stuff (REESE 1987: 203). When the species die, their relevant hypobranchial gland dries out and does not provide the necessary liquid anymore to extract the attractive colour dye from (Ruscillo 2001). The extracted gland was also not supposed to be exposed to light or air/oxygen (REESE 1987: 203). This means that processing the Murex shells for dying had to be carried out close to where they were caught: at the sea front. Although Tell el-Dabca was easily reached from the Mediterranean coast we still do not know how long the trip took. We can therefore, not say with $100 \%$ certainty that it was possible to provide Tell el-Dabca with live specimen in bulk to be processed for the dyeing purpose on the site itself. The processing could still have happened though at some point along the coastline after which the pigment/dye would have been brought in as a usable product. But no evidence has been found at Tell el$\mathrm{Dab}^{\mathrm{c}} \mathrm{a}$, until now, pointing to the existence of the pigment/dye or dyed materials or its industry from this period.

2) The option that these shells came in for consumption needs to be considered as well since occupation levels of the Tuthmosid period have been found in area $\mathrm{H} / \mathrm{I}$, near the foundation platform at H/I (BIETAK 1996). However, the two deposits of Murex shells were found in the close vicinity to a very peculiar plaster feature in area $\mathrm{H} / \mathrm{I}$. Here, an interesting sequence of plaster sloping floors, intermixed with layers of organic material, were uncovered in the Spring of 2001. The dating of these mortar beds is awaiting the pottery analysis of this area. In a few areas, pigmented surfaces were detected on the top layer of these plaster phenomena. This can hardly be seen as a domestic area where food preparing was undertaken so the crushed shells seemed to be there for a different reason. Even if the shells were part of the diet, it is still an oddity in Egypt to see the crushed shells present in lime plaster although it is a very common feature in the plaster floors (or even walls) in the Aegean. As we see, similar crushed shells fragments of three different Murex shell types 
were found, in the plaster matrix, all over the Aegean: Knossos, Chania, Palaikastro and Kato Zakros (for more sites and covering the period from the Neolithic phases onwards see Reese 1987; MACGILLIVRAY et al. 1992: 126-7), in earthen floors at Akrotiri (DoumAs 1983: 117; KARALI 1999: 43-4) and now also at Miletus (personal analysis).

Interestingly, no crushed Murex shells in plaster matrixes have been observed or reported upon from the Mycenean sites on the mainland in Greece nor from Phylakopi although shells formed an aggregate in the plaster matrix at Thebes and Phylakopi but the type of shells was not recorded as Murex shells at the time of its observation. Futhermore, at the time of writing, the plaster from only a few sites on the mainland had been studied in enough detail. Renfrew reported on the presence of only one complete Murex shell from Phylakopi but I recognized at least one other fragment on a photograph from the site (RENFREW 1985: 326, 328). KARALI, however, mentions the presence of pierced Murex shells in Room B of a workshop at Thebes (1999: 38). Murex shells have been reported on the mainland and several islands with Bronze Age occupation levels but not in the context of plaster matrices: Asine, Ayios Kosmas (Attika), Aegina, Troy (Turkey), Minet el Beidha (northern Syria) and Sarepta (Lebanon). On Cyprus (Hala Sultan Tekke), however, the crushed shells were found within Late Cypriot IIIA and IIIA2 lime floors (ca. 1200-1190 BC) (REESE 1987: 205-6). There are various hypotheses that one can formulate around this apparent absence of Murex in plaster on the Greek mainland and other sites:

- The Murex shells were simply not recognized as such within the plaster

- The recovered material did not include the rougher (undecorated) pieces that most often contained the shell fragments, during older excavations

- Since no Murex shells seem to have been used into the plaster matrix on the mainland sites, can we tentatively see this as a technological break or change between the different areas in the Aegean? And what does that tell us about the position of Tell el-Dabca in relation to the Aegean traditions within this craft?

12) Almost all plaster, reported upon in the Aegean, is lime based. In various periods different fillers and combinations have been observed and analysed but there is no evidence of the systematic use of gypsum plaster instead (SHAW 1973, CAMERon et al. 1977,
DANDRAU 2001). Very much the same can now be said from Tell Alalakh and Miletus. Lime plaster was also reported as being the major material for the painted surfaces at Tel Kabri. This is in contrast to what has been reported upon from Egyptian wall paintings for the relevant period (LEE and QUIRKE 2000: 117-8, LUCAS 1962: 74-76).

Without having carried out elemental analysis we can say that, on the basis of a simple chemical test, most of the plaster from Tell el-Dabca was identified as lime plaster. This is a prerequisite to the execution of fresco painting on walls in so much detail. Gypsum plaster would dry too fast and although certain fillers can slow down this drying/curing process, this is not advisable to bulk out gypsum plaster in such a way since it will seriously weaken the plaster matrix and it may not cure at all eventually. I experienced that if close to $10 \%$ of foreign elements or filler are added to a gypsum mixture, it can take several days to dry but it is so weak that is can be crumbled up by hand.

In Egypt, gypsum was the usual raw material source for plastering surfaces. Very often, the quarried gypsum was far from pure and often contained a variable amount of calcium carbonate. According to Lucas, no real lime plaster was found in Egypt before the Ptolemaic period (which may demonstrate that its use was introduced under Greek influence in Egypt from that period onwards). However, it is not a justifiable explanation for the fact that Lucas connected the use of gypsum instead of lime with economical reasons (less fuel necessary for calcination) (LUCAS 1962: 74-5). Although Lee and Quirke mention lime as a raw material for plaster as well, the geological source of plaster is not stated clearly enough in my view to draw unanimous conclusions (LEE and Quirke 2000: 117-8). The fact remains that the plaster in Tell el-Dabca is clearly lime based rather than the usual gypsum based material, found elsewhere in Egyptian painted plaster surfaces.

13) The recycling of older (painted) plaster material within a variety of features and done in several different ways, as we observed at Tell el-Dabca, has been accounted for at Akrotiri (Doumas 1992: 185), Palaikastro, Knossos, Thebes and Miletus (see BRYSBAERT 2003: in press) and seemed to have been common practice within the Aegean plaster craft.

14) A multi-layered stratigraphy has been noticed on material from every single site in the Aegean and Eastern Mediterranean that I have studied, apart from Tell Alalakh. The reason for that may be simply due to the state of preservation of the 
Tell Alalakh material where most material has been embedded in plaster of Paris as an old conservation measure or that no multi-layered material was preserved or collected or that it just simply never existed. The most impressive site from this point of view is without any doubt Palaikastro where the sequences have a high number of layers, very often with plaster in different colours, while these are intersected with differently coloured paint layers.

\section{Conclusion}

In this paper, I demonstrated that iconographical comparative studies, involving the material from Tell el-Dabca and many well-known Aegean sites, are being supported by technological observations, as outlined above, in order to state and confirm a common knowledge and tradition in painting plaster surfaces during the height of the Bronze Age in the broader Eastern Mediterranean. From the presented results that emanated from a preliminary macroscopic and microscopic study combined with experimental and replication work, it should be clear that, first of all, time dedicated to surface and material study without further analysis is justified. It shows the potential for in depth detection levels of very characteristic features that are highly relevant in a comparative study of technological features such as the ones presented here. It should also be clear how interdisciplinary work provides the most interesting and more complete results, even if analytical work has not yet been conducted. Material science studies such as those related to ancient metallurgy, textile production, and experimental replications all provide useful information. Although no one can carry out all levels of a completely integrated study of this material, taking it from each possible angle separately, it is still our task to approach the material in an interdisciplinary fashion in which each of us focuses on a feasible set of meaningful questions. A logical future for the technological study of painted plaster material is the application of analytical techniques and the execution of focused experiments, both of which are undertaken at present.

\section{Acknowledgements}

First of all I wish to thank warmheartedly the entire Austrian team at Tell el-Dabca for their invaluable help and hospitality during my study periods there in 2000 and 2001. My special thanks go to Prof. M. Bietak, Prof. J. Dorner, and Dr. P. Jánosi. Without them, this work and paper would not have been possible. This paper was written while I hold a Research Associateship at the Wiener Laboratory of the American School of Classical Studies at Athens (2001-2).
I benefited greatly from the facilities at the Wiener Laboratory to carry out my work on the sites of Thebes, Glas, Phylakopi and Knossos. Finally, I also wish to thank all the directors of the projects and all involved eforias in Greece that have given me their confidence to work on their material. All opinions and preliminary results presented are mine and are thus open to corrections and alterations subsequent to analytical results. 
Bibliography

BIETAK, M

lii994 Historische und archaeologische Einfuehrung, in: M. BietaK and I. HeIn (eds), Pharaonen und Fremde Dynastien im Dunkel. Katalog zur 194. Sonderausstellung des Historischen Museums der Stadt Wien in Zusammenarbeit mit dem Aegyptologischen Institut der Universitaet Wien und dem Öterreichischen Archäologischen Institut Kairo. Rathaus Wien, Volkshalle, Sept. 8-Oct. 23, 1994, Vienna: Wien Kultur, 17-58

1996 Zum Raumprogramm aegyptischer Wohnhaeuser des Mittleren und des Neuen Reiches, in: M. Bietak (ed.) House and Palace in Ancient Egypt. International Symposium in Cairo, 8-11 April 1992. UZK, 14, Vienna, 23-43

2002 personal communication (email of Jan. 15, 2002)

Birtacha, K. and ZaCHARIOUdAKIS, M.

2000 Stereotypes in Theran wall paintings: modules and patterns in the procedure of painting, in: S. SHERRATT (ed.), The wall paintings of Thera. Proceedings of the first international symposium. Petros M. Nomikos Conference Centre, Thera, Hellas. 30 August-4 September 1997, Athens: Petros M. Nomikos and The Thera Foundation, 159-172

Boessneck J. and Von Den Driesch, A.

1992 Tiere und historische Umwelt im nordost-Delta im 2. Jahrtausand v. Chr. Anhand der Knochenfunde der Ausgrabungen 1975-1986. (Tell el-Dabca, 7), Vienna

BRYSBAERT, A

2000 The role of a field laboratory in the preliminary study of Bronze Age plaster finds from Palaikastro, East Crete. Papers from the Institute of Archaeology 11, $47-60$

2003 in press Rotating Angles in Measuring the Aegean Bronze Age. The Technology of Bronze Age Painted Plaster from the Aegean and Eastern Mediterranean, in: K. Foster and R. LAFFInEUR (eds). METRON. Measuring the Aegean Bronze Age. 9th International Aegean Conference. Yale University, 18-21 April, 2002

in prep. The painted surfaces in the Temple Tomb complex at Knossos, Crete: A technological investigation, in: E.M. HATZAKI, The temple Tomb at Knossos. (British School at Athens, Supplementary vol.)

Cameron M.A.S., Jones R.E. and Philippakis, S.E.

1977 Scientific analysis of Minoan fresco samples from Knossos, BSA 72, 121-184

Chryssikopoulou, E., Kilikoglou V., Perdikatsis V., Sotiropoulou S., Birtacha K. and Zacharioudakis, M.

2000 Making wall paintings: an attempt to reproduce the painting techniques of Bronze Age Thera, in: S. Sherratt (ed.), The wall paintings of Thera. Proceedings of the first international symposium. Petros $M$. Nomikos Conference Centre, Thera, Hellas. 30 August-4 September 1997, Athens, 119-127
DANDRAU, A.

1999 La peinture murale minoenne, I. La palette du peintre égéen et égyptien à l’Âge du Bronze. Nouvelles données analytiques. $B C H$ 123.1, 1-41

2001 La peinture murale minoenne, III, Méthodes et techniques d'exécution, $B C H$ 125.1, 44-66

DAVIES, W.V. (ed.)

2001 Colour and painting in Ancient Egypt. London.

DAVIES, W.V. and L. SCHOFIELD (eds.)

1995 Egypt, the Aegean and the Levant: interconnections in the second millennium BC, London.

DORNER, J.

1999 Die Topographie von Piramesse-Vorbericht, in: $\ddot{A} \mathcal{E} L, 9,77-83$.

DOUMAS, C.

1983 Thera: Pompei of the Ancient Aegean, London

1992 The wall paintings of Thera. Athens.

EL Goresy, A

2000 Polychromatic wall painting decorations in monuments of Pharaonic Egypt: compositions, chronology and painting techniques, in: S. Sherratt (ed.), The wall paintings of Thera. Proceedings of the first international symposium. Petros M. Nomikos Conference Centre, Thera, Hellas. 30 August-4 September 1997, Athens, 49-70

FILIPPAKIS, S.E.

1978 Analysis of pigments from Thera, in: C. Doumas (ed.) Thera and the Aegean world I. London, 599-604

Filippakis, S.E., Perdikatsis, V. and Paradellis, T.

1976 An analysis of blue pigments from the Greek Bronze age, in: Studies in Conservation, 21, 143-153

JONES R.E.

in press Technical Studies of Aegean Bronze Age Wall Painting: Methods, Results and Future Prospects, in: L. Morgan (ed.) Studies in Memory of Mark Cameron. (Annual of the British School at Athens, Supplementary volume)

KARALI, L.

1999 Shells in Aegean prehistory, (BAR, IS, 761), Oxford

LEE, L. and QUIRKE, S.

2000 Painting materials, in: P.T. NichOLSON and I. SHAW (eds.), Ancient Egyptian materials and technology, Cambridge, 104-120

LUCAS, A.

1962 Ancient Egyptian materials and industries. $4^{\text {th }}$ edn. (Rev. J.R. Harris) London

MacGillivray, J.A., SacketT, L.H., Driessen, J.M. and HeMINGWAY, S.

1992 Excavations at Palaikastro 1991, BSA, 87, 121-152

Nicholson, P.T. and SHAW, I. (eds.)

2000 Ancient Egyptian materials and technology, Cambridge 
OGDEN, J.

2000 Metals, in: Nicholson, P.T. and SHAw, I. (eds.) Ancient Egyptian materials and technology, Cambridge, $148-176$

Perdikatsis V., Kilikoglou V., Sotiropoulou S. and Chryssikopoulou E.

2000 Physiochemical characterization of pigments of Theran wall paintings, in: S. SHERratT (ed.), The wall paintings of Thera. Proceedings of the first international symposium. Petros M. Nomikos Conference Centre, Thera, Hellas. 30 August-4 September 1997, Athens: Petros M. Nomikos and The Thera Foundation, 103-118

Poursat J.-P.

1999 Les découvertes de Tell el-Dabca et la Crète, in: A. Caubet (ed.) L'acrobat au taureau. Les découvertes de Tell el-Dab ${ }^{c}$ a (Egypte) et l'archéologie de la Méditerranée orientale (1800-1400 av. J.-C.). Actes du colloque organisé au musée de Louvre par le Service culturel le 3 décembre 1994. Paris: Musée de Louvre, La documentation française, 181-194

REESE, D.S.

1987 Palaikastro shells and Bronze Age purple-dye production in the Mediterranean basin, in: BSA, 82, 201-211

RENFREW, C.

1985 The archaeology of cult. The sanctuary at Phylakopi, (BSA Supplementary volume, 18), London

Ruscillo, D.

2001 To dye for: Making Royal Purple and Biblical Blue from Murex species. The $10^{\text {th }}$ Annual Malcolm H. Wiener Lecture, Athens (Unpublished)

\section{SCHAEFER, J.}

1992 Amnisos. Nach den Archäologischen, Historischen und Epigraphischen Zeugnissen des Altertums und der Neuzeit. Forschungen des Archäologischer Instituts des Universität Heidelberg, Berlin

\section{SHAW, J.W.}

1973 Minoan architecture: materials and techniques, Rome

SEEBER, R.

2000 The technique of plaster preparation for the Minoan wall paintings at Tell el-Dabca, Egypt-Preliminary results, in: S. Sherratt (ed.), The wall paintings of Thera. Proceedings of the first international symposium. Petros M. Nomikos Conference Centre, Thera, Hellas. 30 August-4 September 1997, Athens: Petros M. Nomikos and The Thera Foundation, 91-102

Tite, M.S.

1986 Egyptian blue, faience and related materials: technological investigations, in: R.E. jones and H.W. Catling (eds.) Science in archaeology. (Fitch Laboratory occasional paper, 2), London: BSA, 39-41

Tite, M.S. and Bimson, M.

1987 Identification of early vitreous materials, in: J. Black (ed.) Recent advances in the conservation and analysis of artifacts, London, 81-85

TORNARITIS, G.

1987 Mediterranean sea shells. Cyprus, Nikosia 
